\title{
ENERGY AND THE SCOTLAND ACT 2016
}

\author{
Gavin Little*
}

\section{A. Introduction}

The provision for energy ${ }^{1}$ in the Scotland Act 2016 is piecemeal and lacking substance. Perhaps, given the contested political context from which the Act emerged, it would be surprising if it were otherwise.

Scotland's energy resources, in particular North Sea oil and its renewable energy potential, were significant elements in the case for Scottish independence during the 2014 independence referendum. ${ }^{2}$ In the post-devolution period, and particularly since the election of the first Scottish National Party Scottish Government in 2007, there has been an uneasy relationship between Holyrood and Westminster over energy. It is reserved (with limited exceptions for the promotion of renewable energy and energy efficiency) to the UK Parliament under the Scotland Act $1998^{3}$, but the UK Government is reliant on the exercise by Scottish Ministers of devolved powers in planning and environmental protection to implement onshore energy infrastructure development north of the border, and specific competence over the Renewables Obligation - until recently the main revenue support mechanism for renewable electricity - was executively devolved ten years ago. ${ }^{4}$ Scottish Ministers have therefore blocked new nuclear power stations in Scotland ${ }^{5}$ and forged ahead with an ambitious renewable energy programme. Since the referendum, there has been a spate of UK government decisions on energy, such as the withdrawal of funding for carbon capture and storage development, the closure of the Longannet coal-fired power station and the withdrawal of subsidies for renewable energy. All of them have, whether by accident or design, undermined Scotland's "energy independence" in advance of any second independence referendum. The 2016 Act reflects the ebb and flow of this cross-border constitutional dynamic, and suggest that the wings of the Scottish Government's energy policy are being clipped by Westminster: the Empire is striking back.

In this context, before examining the key provisions of the 2016 Act, it is instructive to first identify what is not in it. Specifically, there is no devolution of control over North Sea oil and gas, or the regulation of the energy industry, energy taxation and energy subsidies: these remain with Westminster. The only measure relating to offshore energy enables Scottish Ministers to act in relation to declaring safety zones around, and the decommissioning of, offshore renewable energy developments in Scottish waters. ${ }^{6}$ The most noteworthy energy provision in the 2016 Act, in line

\footnotetext{
* Professor of Law, Stirling Law School, University of Stirling.

${ }^{1} \mathrm{NB}$ - provision for the Crown Estate is discussed elsewhere in this issue by Aileen McHarg.

2 For example, see Scottish Government Scotland's Future: Your Guide to an Independent Scotland (November 2013) pp 293-306.

${ }^{3}$ Scotland Act 1998 Sched 5 Head D.

${ }^{4}$ Scotland Act 1998 (Transfer of Functions to the Scottish Ministers etc) (No 3) Order 2006 (SI 2006/3258). The Renewables Obligation was replaced with so-called 'contracts for difference' by the Energy Act 2013, which are reserved to the UK Government.

${ }^{5} \mathrm{G}$ Little "The regulation of nuclear installations and radioactive substances in Scotland", in F McManus (ed) Environmental Law in Scotland (2009) paras 9.54-9.63.

${ }^{6}$ Or in a Scottish section of a Renewable Energy Zone: see Scotland Act 2016 s 62.
} 
with the post-referendum Smith Commission report, ${ }^{7}$ is the devolution of control over licensing and mineral rights access for fracking. ${ }^{8}$ The Scottish Government, of course, already had an effective veto over this under the devolved planning and environmental protection regimes, and had put in place a moratorium on the granting of planning consents for all onshore unconventional oil and gas developments, including fracking, pending the outcome of a public consultation. Politically, however, the devolution of more comprehensive fracking controls to Holyrood avoids putting wind in the sails of pro-independence campaigners. Moreover, given the recent UK Government decisions mentioned above, the Scottish Government's energy policy options are now limited: the most obvious way in which it can protect Scotland's energy independence is to proceed with fracking. Given the unpopularity of doing so, this may prove a poisoned chalice for Holyrood: the UK Government was, in all likelihood, not unhappy to devolve responsibility for decision-taking. The other energy powers devolved by the 2016 Act are political window-dressing, and an implicit reassertion of Westminster's strategic control over energy.

What then are the key energy measures introduced by the 2016 Act? It makes provision for four issues. These are, in the order that the Act sets them out, onshore oil and gas extraction; fuel poverty support systems and energy company obligations; a consultative role for the Scottish Government in relation to renewable electricity incentive schemes and the Gas and Electricity Markets Authority.

\section{B. Onshore oil and gas extraction}

Section 47 of the 2016 Act amends the Scotland Act $1998^{9}$ to provide the Scottish Parliament with legislative competence over the granting and regulation of licences to search and bore for and to get petroleum within the Scottish onshore area: such licences include authority to obtain access to land. ${ }^{10}$ Scottish Ministers have also been empowered to exercise the licensing powers held by the UK Secretary of State under the Petroleum Act 1998 and other legislation. ${ }^{11}$ Therefore, as well as authorising conventional onshore oil and natural gas operations, Scottish Ministers are now able to license onshore fracking to extract shale gas or coalbed methane operations. As indicated above, given that there is considerable political controversy surrounding fracking (and the fact that some licenses have already been issued ${ }^{12}$ ), the issue is likely to prove challenging for Holyrood.

It should, however, be noted that underground coal gasification ("UCG") operations do not fall within the formal definition of petroleum, and are instead licensed by the UK Coal Authority. ${ }^{13}$ The Scottish Government was, however, recently able to use its pre-existing control over planning and environmental protection to establish a moratorium on a major UCG project in the Firth of Forth (which although off the coast of Fife, still fell within the onshore baseline boundary). As a result, the

\footnotetext{
${ }^{7}$ Smith Commission, Report of the Smith Commission on further devolution of powers to the Scottish Parliament, November 2014 paras 69-70.

${ }^{8}$ Hydraulic fracturing.

${ }^{9}$ Scotland Act 1998, Sched 5 Part 2 s D2. Section 48 of the 2016 Act makes a number of detailed consequential amendments to give full effect to section 47.

${ }^{10} 2016$ Act s 47 (1), (2).

${ }^{11} 2016$ Act s 48. Petroleum is defined within the meaning of s 1 of the Petroleum Act 1998 to include "mineral oil or relative hydrocarbon and natural gas existing in its natural condition in strata": see Scotland Act $2016 \mathrm{~s}$ 47 (3).

122016 Act s 49 makes provision for existing licenses.

${ }^{13}$ UCG is excluded from the definition of petroleum under the Petroleum Act $1998 \mathrm{~s} 1(2)$.
} 
project was dropped. The failure to devolve the full power to regulate onshore UCG seems to be an obvious omission. It is perhaps explicable by the politicised context of the decision to devolve fracking outlined above: the lack of goodwill between Westminster and the Scottish Government after the independence referendum is such that the former would not favour additional devolution beyond the Smith Report's recommendations.

It should also be observed that, as per paragraph 83 of the Smith Report, the taxation of oil and gas receipts remains reserved to Westminster. Scottish Ministers are therefore not permitted to make provision for any model clauses in licences granted by them relating to the money payable for a licence, which could be seen as a form of taxation. ${ }^{14}$

\section{Fuel poverty support systems}

Section 58 of the 2016 Act amends the Energy Act 2010 and provides for a number of relatively lowkey powers for Scottish Ministers in relation to fuel poverty support schemes. They have been given a role in deciding local aspects of support schemes in Scotland. Importantly, the UK Secretary of State has the key functions of determining the licensed suppliers to whom the scheme should apply, the amount of benefits to be provided by them and the other main issues governing the design and function of the schemes. Scottish Ministers are also subject to the discretion of the UK Secretary of State, who is clearly in control. Thus, they have no right to be consulted by the UK Secretary of State and their exercise of the powers that they do have must be agreed by her - who on the face of it has an absolute discretion when taking a decision. The UK Secretary of State is therefore empowered to establish support schemes in Scotland and to vary and revoke regulations made by Scottish Ministers with and without their agreement in specified circumstances. In the context of the lowintensity conflict between Westminster and Holyrood, these are fairly widely drawn: that is, inter alia, where a support scheme made in relation to Scotland is (in the opinion of the Secretary of State) likely to cause detriment to the UK, or adversely affect the ability of the UK to comply with an international agreement or arrangement in relation to climate change or energy efficiency, and Scottish Ministers have failed to comply with the Secretary of State's wishes. ${ }^{15}$

\section{Energy company obligations}

Section 59 of the 2016 Act makes provision to amend the Gas Act 1986 and the Electricity Act 1989 in order to transfer a number of powers previously held by the Secretary of State dealing with the promotion of reductions in carbon emissions and the costs of home heating in Scotland by gas and electricity supply companies. Accordingly, Scottish Ministers are now able to detail how suppliers may meet the obligations which have been determined and imposed by the Secretary of State, thereby meeting criticisms that such schemes have hitherto failed to take adequate account of the distinctive features of the Scottish energy context, such as the nature of the housing stock. That said, it is clear that, as with fuel poverty and support systems, the Secretary of State is in overall charge. Thus, the powers to decide whether there should be an obligation, the length of obligation periods, the suppliers who are to be subject to obligations, how new suppliers ${ }^{16}$ are to be treated, the

\footnotetext{
${ }^{14}$ Scotland Act 2016 s 48 (7).

${ }^{15}$ Scotland Act 2016 s 58 (3).

${ }^{16}$ I.e. suppliers who enter the market after the obligation period has commenced.
} 
distribution of obligations between suppliers, the power to vary such obligations and to impose obligations on electricity distributors or gas transporters all remain with the Secretary of State.

In this context, before acting, Scottish Ministers must also consult with and obtain the consent of the Secretary of State, and consult with bodies such as the Gas and Electricity Markets Authority, energy suppliers and Citizens Advice Scotland. In order to avoid interfering with UK-wide targets set by the Secretary of State, Scottish Ministers are obliged to ensure that they do not exceed the costs of the obligation that have been apportioned to Scotland. Again, the Secretary of State is able to exercise the powers which have been transferred to Scottish Ministers, either with their agreement or without it, in the event that the actions of Scottish Ministers are likely to be detrimental to the UK, have an adverse effect on the UK's ability to meet international agreements in relation to climate change or energy efficiency, or result in suppliers having to meet costs which are not broadly equivalent in relation to England and Wales and in relation to Scotland. ${ }^{17}$ Section 60 of the 2016 Act makes further provision for inter alia the apportionment by the Secretary of State of overall carbon emission and home-heating cost reduction targets between Scotland and the rest of Great Britain; the ability of suppliers to elect that measures carried out on one side of the border should be treated as being carried out on the other side; and the need for Scottish Ministers to consent to measures which have been carried out in England and Wales being treated as if they had been carried out in Scotland.

\section{E. Renewable electricity incentive scheme consultation and the Gas and Electricity Market Authority}

Finally in relation to energy, section 61 of the 2016 Act introduces a limited ${ }^{18}$ duty for the Secretary of State to consult with Scottish Ministers prior to setting up or amending a renewable electricity incentive scheme. This is, of course, only a duty to consult, and does not prima facie imply anything more than that. Under section 64 of the Act, the Gas and Electricity Market Authority has also been put under a statutory obligation to send a copy of its reports to Scottish Ministers, who must in turn lay a copy of the annual reports before the Scottish Parliament, and under section 66 the authority can now be compelled to appear before the Parliament. The recommendation in the Smith Report that there should be a "formal consultative role for the Scottish Government and the Scottish Parliament in designing renewables incentives and the strategic priorities set out in the Energy Strategy and Policy Statement" ${ }^{19}$ to which the authority must have due regard was not, however, implemented directly in relation to the Scottish Parliament. Scottish Ministers were already statutory consultees, and the 2016 Act puts them on a similar footing to the Secretary of State, who is under a duty to lay the authority's reports before both Houses of Parliament. ${ }^{20}$ This provision looks rather like political window-dressing. It remains to be seen whether the power to compel the authority to appear before the Scottish Parliament will amount to more than that but, given the limited nature of the powers devolved to Scottish Ministers, it may be thought unlikely.

\footnotetext{
${ }^{17}$ Scottish Ministers must also have failed to comply with a written request from the Secretary of State to make modifications.

${ }^{18}$ The Secretary of State is not required to consult inter alia in relation to any levies connected with a scheme, or in relation to minor technical or administrative changes.

${ }^{19}$ Smith Commission, Report of the Smith Commission on further devolution of powers to the Scottish

Parliament, November 2014 para 41.

${ }^{20}$ Scotland Act 2016 s 64 (2).
} 


\section{F. Conclusion}

The Scotland Act 2016, unsurprisingly given the outcome of the 2014 independence referendum, maintains the primacy of the UK Government and Parliament over energy policy and legislation in Scotland. The only significant devolution of authority to Scottish Ministers is in relation to onshore fracking, over which they already had considerable influence through the exercise of pre-existing devolved powers. The other energy related powers devolved to Scottish Ministers by the Act are non-strategic executive functions and consultation and reporting obligations which maintain, and indeed highlight, the overall control of energy decision-taking by the UK Secretary of State. Set against the backdrop of the UK Government's recent decisions on issues such as the abrupt axing of renewables subsidies and support for carbon storage development, and the swift closure of Longannet coal-fired power station, the Act signals the re-assertion of Westminster's control of energy policy in Scotland after attempts by the Scottish Government to establish Scottish energy independence as part of its broader case for political independence. 